\title{
BMJ Open Health impact of work stressors and psychosocial perceptions among French hospital workers during the COVID-19 outbreak: a cross-sectional survey
}

David Lucas (D) , ${ }^{1,2}$ Sandrine Brient, ${ }^{1}$ Bisi Moriamo Eveillard, ${ }^{1}$ Annabelle Gressier, ${ }^{1}$ Tanguy LeGrand, ${ }^{1}$ Richard Pougnet, ${ }^{1}$ Jean-Dominique Dewitte, ${ }^{1}$ Brice Loddé ${ }^{1,2}$

To cite: Lucas D, Brient $\mathrm{S}$, Eveillard BM, et al. Health impact of work stressors and psychosocial perceptions among French hospital workers during the COVID-19 outbreak: a crosssectional survey. BMJ Open 2022;12:e053638. doi:10.1136/ bmjopen-2021-053638

- Prepublication history and additional supplemental material for this paper are available online. To view these files, please visit the journal online (http://dx.doi.org/10.1136/ bmjopen-2021-053638).

Received 24 May 2021 Accepted 03 December 2021

Check for updates

(C) Author(s) (or their employer(s)) 2022. Re-use permitted under CC BY-NC. No commercial re-use. See rights and permissions. Published by BMJ.

${ }^{1}$ Occupational Health Unit, $\mathrm{CHU}$ Brest, Brest, France

${ }^{2}$ Orphy Laboratory, Bretagne Occidentale University, Brest, France

Correspondence to

Dr David Lucas;

david.lucas@chu-brest.fr

\section{ABSTRACT}

Objective To compare global health, mental health impact of work stressors and psychosocial perception of healthcare workers (HCWs) and non-HCWs in a hospital after the first peak of the COVID-19 outbreak in France. Methods A validated version of the SATIN (Santé Au Travail Inrs université Nancy 2)questionnaire with adapted scoring was used to collect data on health and impact of work stressors. This questionnaire was sent to all workers at a hospital in July 2020 and was self-administered online. In a multinomial regression model, we included HCW status, age, gender and front-line worker status as covariates.

Results Data from a total of 1405 participants were included. We found that being an HCW, male and front-line worker was a risk factor for negative perception of work demand (OR $7.35,95 \% \mathrm{Cl} 4.2$ to $11.47 ; \mathrm{OR} 2.55,95 \% \mathrm{Cl}$ 1.11 to 5.89 ; OR $1.78,95 \% \mathrm{Cl} 1.04$ to 3.06 ). Being an HCW was a predictive factor for stress ( $0 \mathrm{R} 1.47,95 \% \mathrm{Cl} 1.04$ to 2.08), poor global health ( $\mathrm{OR} 1.71,95 \% \mathrm{Cl} 1.14$ to 2.55 ) and negative perception of work activity environment ( $\mathrm{OR}$ $1.9,95 \% \mathrm{Cl} 1.3$ to 2.8 ).

Conclusion We have shown that all HCWs suffered from some health impact shortly after the first peak of the COVID-19 outbreak. We underline some stressors with high impact, including work demand, work abilities and organisational context, and emphasise the need for risk management.

\section{INTRODUCTION}

In 2020, the COVID-19 pandemic had an important strengthening effect on healthcare systems, including on healthcare workers (HCWs). The WHO emphasised the high burden on HCWs and called for action to prevent impact on their physical and mental health and to improve mental health and psychological well-being (WHO 2020; https://www.who.int/news/item/1709-2020-keep-health-workers-safe-to-keeppatients-safe-who).

Studies on HCW well-being and mental health have regularly reported problems such as symptoms of post-traumatic stress,

\section{Strengths and limitations of this study}

- We include a large population of workers from the same healthcare structure (a variety of occupation type, age and years at workplace)

- This approach could limit demographic bias such as lifestyle factors and incidence of COVID-19 infection during the study period.

- The standardised validated questionnaire on global health and psychosocial factors used in the study was in French and was built for big companies.

- Data were self-reported and the time required to complete the survey was almost $15 \mathrm{~min}$, which could have increased response bias.

- The study also lacks longitudinal follow-up and did not take into account any pre-existing health symptoms or psychosocial factors.

burnout, depression and anxiety associated with their occupational activities both during epidemics and at other times. ${ }^{12}$

During the COVID-19 pandemic, a large number of studies have been published on its mental health impact on HCWs. ${ }^{3-6}$ In a recent systematic review of the mental health impact of the COVID-19 pandemic on HCWs, Muller et at identified 189 studies and focused on 59 of them. In their review, the authors concluded that HCWs reported more anxiety, depression and sleep problems than the general population, a finding echoed by other reviews in this field. ${ }^{56}$ In a community-based review, the pooled prevalence of depression among HCWs was $25 \%$, and more precisely in a recent meta-analysis on more studies the pooled prevalence of depression was 25\% among nurses, $24 \%$ among medical doctors and $43 \%$ among front-line professionals. ${ }^{78} \mathrm{~A}$ meta-analysis of 72 studies also found a pooled prevalence of anxiety of 25\% among HCWs, $27 \%$ among nurses, $17 \%$ among medical doctors 
and $43 \%$ among front-line HCWs. ${ }^{9}$ In a recent updated meta-analysis of community-based studies, the prevalence of anxiety was $25 \% .{ }^{10}$ Not only front-line but also second-line HCWs reported mental health impact. ${ }^{11} 12$ Factors reported to correlate with mental health problems include, first and foremost, exposure to COVID-19, followed by female gender and worries about infection. ${ }^{4}$ On the contrary, social support and having protective equipment were correlated with less reports of mental health problems. ${ }^{4}{ }^{13}$ Davido et $a l^{14}$ demonstrated that COVID-19 infection in the part of HCWs is linked to non-adapted respiratory protection. The strategies and resources used by HCWs to help themselves during the pandemic include support from family or friends. ${ }^{4}$ In a study including nurses, all HCWs used active psychological mechanisms such as mindfulness or more passive strategies such as distraction. ${ }^{4}$

Few studies provide data on physical symptoms and/ or work stressors such as organisation, work activity and activity management. Indeed, the majority of participants in these studies were HCWs, including physicians and nurses, and the comparisons focused on whether these HCWs were working in contact with patients with COVID-19 or not. The studies themselves were also performed during a crisis period. During such a period, all HCWs were exposed to mental health burden factors, such as uncertainty, workload, activity management and organisational context modifications. Analysis of previous major incidents called not only for specific programmes for use during crises but also ones that prevent long-term damage to HCWs. ${ }^{15}$ The incidence rate of COVID-19 and the pressure on hospital organisation were not the same in all parts of France and Europe. In Spain, a questionnaire survey found higher levels of psychiatric disorders in HCWs, especially in nurses, in cases of actual COVID-19 infection and when the amount of information provided about the disease was lower. ${ }^{13}$ In Switzerland, the authors of two online cross-sectional studies, conducted at the height of the pandemic and after the flattening of the curve, did not find any difference in the results in terms of depression, burnout and anxiety in the HCW population. ${ }^{16}$ To design and implement a long-term programme, data on psychosocial factors and their impact on mental health are needed. ${ }^{17}$

In France, the impact of the COVID-19 pandemic on the healthcare system began in February 2020, with a peak of hospitalisations in March. A decrease in hospitalised patients with COVID-19 took place through the spring, and restrictions on movements of the population were lifted on 7 May 2020.

Santé Au Travail Inrs université Nancy 2 (SATIN) is a transversal questionnaire developed for preventive medicine that targets well-being at work by the National Institute of Research on Security in France. It assesses physical and psychological health, work environment, and psychosocial factors. It was built based on theoretical models of occupational stress and has been validated in recent studies. $^{1819}$
The aim of this study is to assess workers' overall health (mental and physical), impact of worker stressors on health and psychosocial perception in a French teaching hospital during the first peak of COVID-19 in France. To date, there has been no study on mental health impact and psychosocial factors assessed by validated questionnaire that includes all hospital workers (healthcare and non-healthcare) in Europe.

\section{METHODS}

This was a cross-sectional questionnaire study. The survey was anonymous and confidentiality of information was assured.

We invited all professionals in our hospital to respond to an electronic questionnaire. The questionnaire was sent to each worker by email through their professional address. Answers were all self-reported. A contact (phone and email) for information and questions about the study and the questionnaire was also sent. Two other emails were sent to workers at the middle and 2 weeks before the end of the inclusion period.

\section{Participants}

The survey was conducted between 1 July and 31 August 2020 and involved all workers employed in a teaching hospital in France. The total number of workers was 7299.

The inclusion criteria were as follows: working in the hospital for more than 1 year, adults over 18 years and acceptance of participation in the study.

\section{Questionnaire}

After seeking permission from the authors of the SATIN questionnaire, we created a specific questionnaire with all original questions and some additional questions on workplace and demographics (supplemental file 1). The first question asked participants to check if they have met the inclusion criteria and that they agree to be included in the survey. An open question for additional remarks was available at the end of the questionnaire.

There were 86 questions divided into 6 parts: (1) personal and professional identification (10 questions); (2) health reports (16 questions); (3) work strain and capacities (8 questions); (4) work environment (39 questions); (5) work assessment (4 questions); and (6) supplementary questions for occupational physicians (9 questions).

Each question had five possible answers and each answer was linked to a specific score. The mean of the scores was calculated for each part of the questionnaire: health reports (physical health, self-evaluation of health and compared with the next year), mental health (selfevaluation of mental health, confidence in the future), physical symptoms (musculoskeletal disorders), psychosomatic symptoms (headache, sleep problems, gastrointestinal problems), stress (feeling stressed, exhausted at work, crack-up because of the job), work strain (physical, emotional, concentration, knowledge), work abilities 
(physical, emotional, concentration, knowledge), work environment (physical environment), work activity (interest, variety, utility, responsibility, diversity, quality of social relations), framework of activities (clarity, consistency, latitude, support, interruptions), organisational context (number of hours, financial support, salary communication, job security, job career), and selfassessment of work conditions in their entirety.

The scores for each part were interpreted as follows: $<2.5$ for poor health or negative perception, 2.5-3.5 for mild health or perception, and $>3.5$ for good health or positive perception. Global health and general workplace environment self-evaluation were scored twice with, respectively, health reports and working environment scores.

Demographic data were self-reported by the participants, including occupation, sex (male/female), age $(<35,35-44,45-54,>55$ years $)$, years at workplace $(<5$, $6-15,16-26,>26$ years), and shift work or night work (never, rarely, regularly, often/very often).

\section{Statistical analyses}

Data analysis was performed using $\mathrm{R}$ software ( $\mathrm{R}$ Foundation for Statistical Computing, Vienna, Austria). The results for continuous variables are shown as median with IQR. Ranked data, which were ranked from each part of the questionnaire, are presented as number and percentage. Participants were divided into three groups according to the previously reported questionnaire cut-off $(<2.5,2.5-3.5,>3.5)$. Doctors, nurses, medical students, nurse assistants, midwife, paramedics, physiotherapists and radiographers were included in the subgroup 'health care worker'; other participants were included in the subgroup 'non healthcare worker'. We also performed an analysis by subgroup of workers according to whether they regularly worked or not in a COVID-19-dedicated sector. A multinomial logistic regression analysis was performed and the associations between risk factors and outcomes are presented as OR and 95\% CI after adjustment for confounders including, gender, age and years at workplace. Significant level was set at $\mathrm{p}=0.05$.

\section{Patient and public involvement}

Patients or the public were not involved in the design, or conduct, or reporting or dissemination plans of our research. Results will be made available to all staff and participants through our usual communication channels.

\section{RESULTS}

In this study, 1407 workers completed the survey. Two workers did not complete all questions and were thus excluded. There were 1405 workers available for analysis, including 931 HCWs (66.2\%) (online supplemental figure 1 shows the flow diagram). A higher proportion of participants were women $(1113,79.2 \%)$, were aged $35-44$ years $(426,30.2 \%)$, with experience in the hospital of about $6-15$ years $(516,36.7 \%)$, never do night work
$(725,51 \%)$ and always work on shift hours $(435,29.1 \%)$. We did not find significant differences between participants and the total population in terms of gender (female $74.4 \%$, male $25.6 \%)$ and age (<25 years: $2.9 \%$; $25-34$ years: $30.6 \%$; $35-44$ years: $28.3 \%$; $45-54$ years: $25.8 \%$; and $<55$ years: $12.4 \%$ ). We did not have other data for shift work and years at workplace. The demographic and occupational data of participants are described in table 1.

The answers to the questionnaire and their scores are described in table 2.

A high proportion of workers reported stress $(32.66 \%)$, physical symptoms $(31.38 \%)$ and negative perception of work demand $(31.88 \%)$. For work environment, mild and low scores were reported by $67.26 \%$ for work activity environment and $82.26 \%$ for organisational context, as well as $61.94 \%$ for general health.

In the univariate analysis (online supplemental table 1), HCWs reported more severe scores for mental health (OR 1.45, 95\% CI 1.05 to 2.01, $\mathrm{p}=0.02$ ), stress (OR 1.47, $95 \%$ CI 1.09 to $1.99, \mathrm{p}=0.01$ ), work demand (OR 6.27, $95 \%$ CI 4.2 to $9.2, \mathrm{p}<0.0001)$, physical environment (OR 2.53, 95\% CI 1.8 to $3.55, \mathrm{p}<0.0001$ ), work activity environment (OR 2.19, 95\% CI 1.55 to $3.1, \mathrm{p}<0.0001$ ) and organisational context (OR 2.28, 95\% CI 1.61 to $3.23, \mathrm{p}<0.0001)$. By gender, we found for men higher risk of mental health (OR 1.44, 95\% CI 1.02 to 2.02, $\mathrm{p}=0.03$ ), work demand (OR 1.81, 95\% CI 1.12 to 2.92, $\mathrm{p}=0.01$ ), framework of activities (OR 1.95, 95\% CI 1.36 to $2.81, \mathrm{p}<0.0001)$ and organisational context (OR 1.62, $95 \%$ CI 1.09 to 2.4, $\mathrm{p}=0.01$ ). On the contrary, being male is a preventive factor for physical symptoms (OR 0.39, $95 \%$ CI 0.28 to $0.54, \mathrm{p}<0.001$ ), psychosomatic symptoms (OR $0.43,95 \%$ CI 0.25 to $0.76, \mathrm{p}=0.003$ ), stress (OR $0.61,95 \%$ CI 0.44 to $0.86, \mathrm{p}<0.0001)$ and general health reported (OR $0.43,95 \%$ CI 0.23 to $0.95, \mathrm{p}=0.02$ ). Working in a COVID-19 sector was associated with work demand (OR 2.26, 95\% CI 1.16 to $4.41, \mathrm{p}=0.04$ ) and organisational context (OR 2.05, 95\% CI 1.2 to 3.52, $\mathrm{p}=0.009$ ). All data of the univariate analysis are shown in online supplemental table 1.

Declaring 'often shift work' was an associated factor for poor mental health (OR 1.75, 95\% CI 1.12 to 2.8, $\mathrm{p}=0.009$ ), global health (OR $1.75,95 \%$ CI 1.12 to 2.8), stress (OR 1.76, 95\% CI 1.17 to 2.6, $\mathrm{p}=0.007$ ), negative perception of work abilities (OR 2.95, 95\% CI 1.87 to $4.65, \mathrm{p}<0.0001$ ), organisational context (OR 2.32, 95\% CI 1.49 to $3.6, \mathrm{p}=0.001$ ) and work environment (OR 2.59, $95 \%$ CI 1.52 to $4.19, \mathrm{p}<0.0001)$. Night work was an associated factor for poor mental health (OR 1.02, 95\% CI 1.08 to $3.78, \mathrm{p}=0.02$ ), negative perception of work activity (OR $6.93,95 \%$ CI 2.37 to $20.27, \mathrm{p}<0.0001)$ and global work environment (OR 3.56, 95\% CI 1.27 to 9.69 , $\mathrm{p}=0.01$ ).

The results of the multinomial regression in the multivariate analysis are shown in table 3 .

Low is defined as a low score of $<2.5$ (bad health or negative perception) on the SATIN questionnaire, a medium score is between 2.5 and 3.5, and a high score is $>3.5$ (good health or positive perception). 
Table 1 Demographics and occupational characteristics of
the population

\begin{tabular}{|c|c|c|c|}
\hline & & $\mathbf{n}$ & $\%$ \\
\hline \multirow[t]{13}{*}{ Occupation } & Nurse & 371 & 26.4 \\
\hline & Nurse assistant & 189 & 13.4 \\
\hline & Administrative assistant & 141 & 10 \\
\hline & Doctor & 141 & 10 \\
\hline & Medical student & 122 & 8.7 \\
\hline & Health supervisor & 82 & 5.8 \\
\hline & Radiographer & 63 & 4.5 \\
\hline & Laboratory technician & 43 & 3.1 \\
\hline & Health manager & 28 & 2 \\
\hline & Technicians & 25 & 1.8 \\
\hline & Physiotherapist & 23 & 1.6 \\
\hline & Midwife & 16 & 1.1 \\
\hline & $\begin{array}{l}\text { Others (paramedic, research, } \\
\text { maintenance and cook staff, } \\
\text { psychologist) }\end{array}$ & 155 & 11 \\
\hline \multirow[t]{5}{*}{ Age in years } & $<25$ & 39 & 2.7 \\
\hline & $25-34$ & 396 & 28.2 \\
\hline & $35-44$ & 426 & 30.3 \\
\hline & $45-54$ & 370 & 26.3 \\
\hline & $>55$ & 174 & 12.4 \\
\hline \multirow[t]{4}{*}{ Night work } & Never & 725 & 51.6 \\
\hline & Rarely & 342 & 24.3 \\
\hline & Regularly & 92 & 6.5 \\
\hline & Often/very often & 81 & 5.7 \\
\hline \multirow[t]{4}{*}{ Shift work } & Never & 420 & 28.1 \\
\hline & Rarely & 313 & 20.9 \\
\hline & Regularly & 329 & 22 \\
\hline & Often/very often & 435 & 29.1 \\
\hline \multirow{5}{*}{$\begin{array}{l}\text { Years at } \\
\text { workplace }\end{array}$} & $<1$ & 334 & 23.8 \\
\hline & $16-25$ & 319 & 22.7 \\
\hline & 26 & 144 & 10.2 \\
\hline & $6-15$ & 516 & 36.7 \\
\hline & $1-5$ & 257 & 18.3 \\
\hline \multirow[t]{2}{*}{ Work status } & Non-healthcare & 474 & 33.7 \\
\hline & Healthcare & 931 & 66.2 \\
\hline \multirow{2}{*}{$\begin{array}{l}\text { Front-line } \\
\text { worker }\end{array}$} & Yes & 173 & 12.3 \\
\hline & No & 1232 & 87.7 \\
\hline \multirow[t]{2}{*}{ Gender } & Female & 1113 & 79.2 \\
\hline & Male & 292 & 20.8 \\
\hline
\end{tabular}

A subgroup of HCWs had an increased risk of self-reported stress (OR 1.47, 95\% CI 1.04 to 2.08, $\mathrm{p}=0.04$ ), poor psychical health (OR 1.4, 95\% CI 1 to 2, $\mathrm{p}=0.03$ ) and global health (OR 1.71, 95\% CI 1.14 to 2.55, $\mathrm{p}=0.009$ ), negative perception of work demand (OR 7.35, 95\% CI 4.2 to 11.47 , p<0.0001),
Table 2 Severity categories of different questionnaire part in total population

\begin{tabular}{|c|c|c|c|}
\hline Outcome & $\begin{array}{l}\text { Class of SATIN } \\
\text { questionnaire } \\
\text { score }\end{array}$ & $\mathbf{n}$ & $\%$ \\
\hline \multirow[t]{3}{*}{ Physical health } & $<2.5$ & 867 & 61.7 \\
\hline & $2.5-3.5$ & 444 & 31.6 \\
\hline & $>3.5$ & 94 & 6 \\
\hline \multirow[t]{3}{*}{ Mental health } & $<2.5$ & 667 & 47.4 \\
\hline & $2.5-3.5$ & 498 & 35.4 \\
\hline & $>3.5$ & 240 & 17 \\
\hline \multirow[t]{3}{*}{ Physical symptoms } & $<2.5$ & 590 & 41.9 \\
\hline & $2.5-3.5$ & 374 & 26.6 \\
\hline & $>3.5$ & 441 & 31.4 \\
\hline \multirow{3}{*}{$\begin{array}{l}\text { Psychosomatic } \\
\text { symptoms }\end{array}$} & $<2.5$ & 800 & 56.9 \\
\hline & $2.5-3.5$ & 479 & 34.1 \\
\hline & $>3.5$ & 126 & 8.9 \\
\hline \multirow[t]{3}{*}{ Stress } & $<2.5$ & 334 & 23.7 \\
\hline & $2.5-3.5$ & 612 & 43.5 \\
\hline & $>3.5$ & 459 & 32.7 \\
\hline \multirow[t]{3}{*}{ Work demand } & $<2.5$ & 166 & 11.8 \\
\hline & $2.5-3.5$ & 791 & 56.3 \\
\hline & $>3.5$ & 448 & 31.8 \\
\hline \multirow[t]{3}{*}{ Abilities } & $<2.5$ & 222 & 15.8 \\
\hline & $2.5-3.5$ & 1115 & 79.3 \\
\hline & $>3.5$ & 68 & 4.8 \\
\hline \multirow{3}{*}{$\begin{array}{l}\text { Physical } \\
\text { environment }\end{array}$} & $<25$ & 397 & 28.2 \\
\hline & $2.5-3.5$ & 730 & 51.9 \\
\hline & $>3.5$ & 278 & 19.7 \\
\hline \multirow[t]{3}{*}{ Work activity } & $<2.5$ & 1093 & 77.8 \\
\hline & $2.5-3.5$ & 272 & 19.3 \\
\hline & $>3.5$ & 40 & 2.8 \\
\hline \multirow{3}{*}{$\begin{array}{l}\text { Work activity } \\
\text { environment }\end{array}$} & $<2.5$ & 460 & 32.7 \\
\hline & $2.5-3.5$ & 695 & 49.4 \\
\hline & $>3.5$ & 250 & 17.8 \\
\hline \multirow{3}{*}{$\begin{array}{l}\text { Organisational } \\
\text { context }\end{array}$} & $<2.5$ & 249 & 17.7 \\
\hline & $2.5-3.5$ & 788 & 56.1 \\
\hline & $>3.5$ & 368 & 262 \\
\hline \multirow{3}{*}{$\begin{array}{l}\text { Global work } \\
\text { environment }\end{array}$} & $<2.5$ & 973 & 69.2 \\
\hline & $2.5-3.5$ & 390 & 27.7 \\
\hline & $>3.5$ & 42 & 2.9 \\
\hline \multirow{3}{*}{$\begin{array}{l}\text { Global work } \\
\text { assessment }\end{array}$} & $<2.5$ & 1061 & 75.5 \\
\hline & $2.5-3.5$ & 272 & 19.4 \\
\hline & $>3.5$ & 72 & 5.2 \\
\hline \multirow[t]{3}{*}{ Global health } & $<2.5$ & 527 & 37.5 \\
\hline & $2.5-3.5$ & 672 & 47.8 \\
\hline & $>3.5$ & 206 & 14.6 \\
\hline
\end{tabular}

SATIN (Santé Au Travail Inrs université Nancy 2) 
Table 3 Multivariate analysis adjustment for confounders including, gender, age and years at workplace

\begin{tabular}{|c|c|c|c|c|c|c|}
\hline & \multicolumn{2}{|c|}{ Mental health } & \multicolumn{2}{|c|}{ Physical symptoms } & \multicolumn{2}{|c|}{ Stress } \\
\hline & Medium/high & Low/high & Medium/high & Low/high & Medium/high & Low/high \\
\hline \multicolumn{7}{|l|}{ Age in years } \\
\hline$<35$ & $0.52(0.4 \text { to } 0.69)^{*}$ & $0.5(0.35 \text { to } 0.71)^{*}$ & $0.48(0.36 \text { to } 0.64)^{*}$ & $0.33(0.24 \text { to } 0.44)^{*}$ & 0.91 (0.64 to 1.27$)$ & 0.7 (0.49 to 1.02$)$ \\
\hline $35-44$ & 1 & 1 & 1 & 1 & 1 & 1 \\
\hline $45-54$ & $1.6(1.1$ to 2.4$) \dagger$ & $1.21(0.75$ to 2.1$)$ & $1.2(0.7$ to 2$) \dagger$ & $2.7(1.8 \text { to } 4)^{\star}$ & 1.34 (0.92 to 1.94$)$ & 1.33 (0.9 to 1.95$)$ \\
\hline$>55$ & 0.72 (0.5 to 1.04$)$ & $0.6(0.37$ to 0.99$) \ddagger$ & $0.6(0.38$ to 0.96$) \ddagger$ & 1.32 (0.9 to 1.92$)$ & 1.5 (0.94 to 2.4$)$ & $1.12(0.68$ to 1.86$)$ \\
\hline $\begin{array}{l}\text { Healthcare } \\
\text { worker } \\
(\text { ref }=\text { no) }\end{array}$ & $1.33(1.01$ to 1.75$) \dagger$ & $1.4(1$ to 2$) \ddagger$ & 1.18 (0.86 to 1.62$)$ & 1.3 (0.96 to 1.75$)$ & 1.04 (0.75 to 1.44$)$ & 1.47 (1.04 to 2.08$) \ddagger$ \\
\hline $\begin{array}{l}\text { COVID-19 } \\
\text { sector } \\
\text { (ref=no) }\end{array}$ & $1.02(0.71$ to 1.45$)$ & 0.82 (0.51 to 4.16$)$ & 1.07 (0.7 to 1.62$)$ & 1.46 (0.99 to 2.16$)$ & $1.1(0.72$ to 1.69$)$ & $1.16(0.74$ to 1.81$)$ \\
\hline $\begin{array}{l}\text { Gender } \\
\text { (ref=female) }\end{array}$ & 0.92 (0.53 to 1.6$)$ & $2.5(1.2$ to 4.19$) \dagger$ & $0.62(0.35$ to 1.11$)$ & $0.42(0.23 \text { to } 0.78)^{*}$ & $0.43(0.25 \text { to } 0.75)^{*}$ & $0.42(0.22 \text { to } 0.8)^{\star}$ \\
\hline
\end{tabular}

\begin{tabular}{|c|c|c|c|c|c|c|}
\hline & \multicolumn{2}{|c|}{ Work demand } & \multicolumn{2}{|c|}{ Work abilities } & \multicolumn{2}{|c|}{ Physical environment } \\
\hline & Medium/high & Low high & Medium/high & Low/high & Medium/high & Low/high \\
\hline \multicolumn{7}{|l|}{ Age in years } \\
\hline$<35$ & 0.69 (0.44 to 1.08$)$ & $0.54(0.33$ to 0.87$) \dagger$ & $0.57(0.39$ to 0.84$) \ddagger$ & $0.4(0.19$ to 0.84$) \dagger$ & 0.81 (0.59 to 1.12$)$ & $0.97(0.52$ to 1.13$)$ \\
\hline $35-44$ & 1 & 1 & 1 & 1 & 1 & 1 \\
\hline $45-54$ & $1.6(1.1$ to 2.4$) \dagger$ & $1.21(0.75$ to 2.1$)$ & $1.2(0.7$ to 2$) \dagger$ & $2.7(1.8 \text { to } 4)^{*}$ & 1.34 (0.92 to 1.94$)$ & 1.33 (0.9 to 1.95$)$ \\
\hline$>55$ & $0.72(0.5$ to 1.04$)$ & $0.6(0.37$ to 0.99$) \ddagger$ & $0.6(0.38$ to 0.96$) \ddagger$ & $1.32(0.9$ to 1.92$)$ & 1.5 (0.94 to 2.4$)$ & $1.12(0.68$ to 1.86$)$ \\
\hline $\begin{array}{l}\text { Healthcare } \\
\text { worker } \\
\text { (ref=no) }\end{array}$ & $1.33(1.01$ to 1.75$) \dagger$ & $1.4(1$ to 2$) \ddagger$ & 1.18 (0.86 to 1.62$)$ & $1.3(0.96$ to 1.75$)$ & $1.04(0.75$ to 1.44$)$ & $1.47(1.04$ to 2.08$) \ddagger$ \\
\hline $\begin{array}{l}\text { COVID-19 } \\
\text { sector } \\
\text { (ref=no) }\end{array}$ & $1.02(0.71$ to 1.45$)$ & 0.82 (0.51 to 4.16$)$ & 1.07 (0.7 to 1.62$)$ & 1.46 (0.99 to 2.16$)$ & $1.1(0.72$ to 1.69$)$ & $1.16(0.74$ to 1.81$)$ \\
\hline $\begin{array}{l}\text { Gender } \\
\text { (ref=female) }\end{array}$ & $0.92(0.53$ to 1.6$)$ & $2.5(1.2$ to 4.19$) \dagger$ & $0.62(0.35$ to 1.11$)$ & $0.42(0.23 \text { to } 0.78)^{*}$ & $0.43(0.25 \text { to } 0.75)^{*}$ & $0.42(0.22 \text { to } 0.8)^{\star}$ \\
\hline
\end{tabular}

\begin{tabular}{|c|c|c|c|c|c|c|}
\hline & \multicolumn{2}{|c|}{ Work activity } & \multicolumn{2}{|c|}{ Work activity environment } & \multicolumn{2}{|c|}{ Organisational context } \\
\hline & Medium/high & Low/high & Medium/high & Low/high & Medium/high & Low/high \\
\hline \multicolumn{7}{|l|}{ Age in years } \\
\hline$<35$ & $0.59(0.43$ to 0.82$) \ddagger$ & $0.6(0.27$ to 1.32$)$ & $0.92(0.68$ to 1.25$)$ & $0.66(0.44$ to 0.99$) \ddagger$ & $0.69(0.47$ to 1$)$ & 0.61 (0.4 to 0.92$)$ \\
\hline $35-44$ & 1 & 1 & 1 & 1 & 1 & 1 \\
\hline $45-54$ & $1.1(0.1$ to 8.5$)$ & $1.3(0.9$ to 2$)$ & 1.26 (0.91 to 1.75$)$ & $1.14(0.75$ to 1.72$) \ddagger$ & $1.11(0.74$ to 1.67$)$ & $1.05(0.67$ to 1.65$)$ \\
\hline$>55$ & $0.92(0.61$ to 1.4$)$ & 1.05 (0.42 to 2.64$)$ & 0.91 (0.61 to 1.36$)$ & 0.73 (0.43 to 1.26$)$ & $0.71(0.45$ to 1.14$)$ & $0.61(0.35$ to 1.05$)$ \\
\hline $\begin{array}{l}\text { Healthcare } \\
\text { worker } \\
\text { (ref=no) }\end{array}$ & 1.15 (0.83 to 1.59$)$ & 0.78 (0.35 to 1.73$)$ & $1.33(1.02$ to 1.72$) \ddagger$ & $2.02(1.4 \text { to } 2.92)^{\star}$ & 1.27 (0.93 to 1.73$)$ & $2.04(1.41 \text { to } 2.96)^{\star}$ \\
\hline $\begin{array}{l}\text { COVID-19 } \\
\text { sector } \\
\text { (ref=no) }\end{array}$ & $0.9(0.59$ to 1.37$)$ & 0.18 (0.02 to 1.36$)$ & $1.28(0.88$ to 1.47$)$ & 1.01 (0.61 to 1.67$)$ & 1.37 (0.82 to 2.26$)$ & $1.78(1.04$ to 3.06$) \ddagger$ \\
\hline \multirow{3}{*}{$\begin{array}{l}\text { Gender } \\
\text { (ref=female) }\end{array}$} & 1.6 (0.91 to 2.83$) 0.1$ & $2.85(1.01$ to 8.02$) \dagger$ & $1.2(0.8$ to 1.6$)$ & $1.9(1.3 \text { to } 2.8)^{\star}$ & 0.59 (0.33 to 1.05$)$ & $1.26(0.64$ to 2.47$)$ \\
\hline & \multicolumn{2}{|c|}{ Global work environment } & \multicolumn{2}{|c|}{ Global work assessment } & \multicolumn{2}{|c|}{ Global health } \\
\hline & Medium/high & Low/high & Medium/high & Low/high & Medium/high & Low/high \\
\hline \multicolumn{7}{|l|}{ Age in years } \\
\hline$<35$ & $0.51(0.38 \text { to } 0.67)^{\star}$ & $0.33(0.13$ to 0.81$) \dagger$ & $0.58(0.42 \text { to } 0.8)^{\star}$ & 0.58 (0.31 to 1.07$)$ & $0.48(0.37 \text { to } 0.63)^{\star}$ & $0.26(0.17 \text { to } 0.39)^{\star}$ \\
\hline $35-44$ & 1 & 1 & 1 & 1 & 1 & 1 \\
\hline $45-54$ & $1.8(1.2$ to 2.7$) \dagger$ & 2 (0.6 to 6.4$)$ & $1.19(0.87$ to 1.67$)$ & $1.08(0.62$ to 1.89$)$ & 1.6 (1 to 1.89$)$ & 1.44 (0.98 to 2.41$)$ \\
\hline$>55$ & $1.11(0.78$ to 1.6$)$ & $1.64(0.75$ to 3.61$)$ & $0.68(0.43$ to 1.06$)$ & 1.21 (0.63 to 2.32$)$ & 0.91 (0.63 to 1.32$)$ & $0.78(0.47$ to 1.3$)$ \\
\hline $\begin{array}{l}\text { Healthcare } \\
\text { worker } \\
\text { (ref=no) }\end{array}$ & $1.34(1.03$ to 1.76$) \dagger$ & 1.35 (0.67 to 2.68$)$ & 1.34 (0.96 to 1.87$)$ & 0.94 (0.31 to 2.81$)$ & $1.33(1.01$ to 1.76$) \dagger$ & $1.71(1.14 \text { to } 2.55)^{*}$ \\
\hline $\begin{array}{l}\text { COVID-19 } \\
\text { sector } \\
\text { (ref=no) }\end{array}$ & $1.17(0.82$ to 1.68$)$ & 0.88 (0.3 to 2.57$)$ & 0.98 (0.65 to 1.46$)$ & 0.7 (0.29 to 1.68) & $1.17(0.81$ to 1.69$)$ & 1.43 (0.88 to 2.33$)$ \\
\hline
\end{tabular}

Continued 
Table 3 Continued

\begin{tabular}{|c|c|c|c|c|c|c|}
\hline & \multicolumn{2}{|c|}{ Global work environment } & \multicolumn{2}{|c|}{ Global work assessment } & \multicolumn{2}{|c|}{ Global health } \\
\hline & Medium/high & Low/high & Medium/high & Low/high & Medium/high & Low/high \\
\hline $\begin{array}{l}\text { Gender } \\
\text { (ref=female) }\end{array}$ & $0.56(0.3$ to 1.04$)$ & $3.16(1.05$ to 9.5$) \ddagger$ & $1.18(0.62$ to 2.21$)$ & 1.75 (0.77 to 3.94$)$ & $0.5(0.3 \text { to } 0.84)^{\star}$ & 0.62 (0.28 to 1.33$)$ \\
\hline
\end{tabular}

\begin{tabular}{|c|c|c|c|c|}
\hline & \multicolumn{2}{|c|}{ Psychosomatic symptoms } & \multicolumn{2}{|c|}{ Physical health } \\
\hline & Medium/high & Low/high & Medium/high & Low/high \\
\hline \multicolumn{5}{|l|}{ Age in years } \\
\hline$<35$ & 0.95 (0.73 to 1.55$)$ & 0.56 (0.34 to 0.92$)$ & $0.42(0.32 \text { to } 0.6)^{*}$ & $0.73(0.45$ to 1.19$)$ \\
\hline $35-44$ & 1 & 1 & 1 & 1 \\
\hline $45-54$ & 1.29 (0.97 to 1.71$)$ & 1.09 (0.7 to 1.7$)$ & $1.2(0.8$ to 1.7$)$ & 1.6 (0.8 to 3$)$ \\
\hline$>55$ & $1.6(1$ to 2.5$) \ddagger$ & $0.8(0.3$ to 1.9$)$ & 0.95 (0.67 to 1.35$)$ & 1.06 (0.54 to 2.07$)$ \\
\hline $\begin{array}{l}\text { Healthcare } \\
\text { worker } \\
\text { (ref=no) }\end{array}$ & $1.2(0.93$ to 1.55$)$ & 0.95 (0.63 to 1.44$)$ & $1.42(1.07$ to 1.87$) \dagger$ & 1.59 (0.92 to 2.74$)$ \\
\hline $\begin{array}{l}\text { COVID-19 } \\
\text { sector } \\
\text { (ref=no) }\end{array}$ & $1.26(0.89$ to 1.78$)$ & 1.07 (0.59 to 1.93$)$ & 1.16 (0.81 to 1.66$)$ & 1.06 (0.55 to 2.03$)$ \\
\hline $\begin{array}{l}\text { Gender } \\
\text { (ref=female) }\end{array}$ & $0.51(0.29$ to 0.88$) \dagger$ & $0.21(0.06$ to 0.7$) \dagger$ & $1.67(1.01$ to 2.76$) \ddagger$ & $1.69(0.64$ to 4.4$)$ \\
\hline
\end{tabular}

Associations between risk factors and outcomes are presented as OR and 95\% Cl.

${ }^{*} \mathrm{P}<0.001$.

$\dagger P<0.01$.

$\ddagger \mathrm{P}<0.05$.

ref, reference.

abilities (OR 2.91, 95\% CI 1.39 to 6.11), physical environment (OR 2.44, $95 \%$ CI 1.66 to $3.59, \mathrm{p}<0.0001$ ), framework of activities (OR 2.02, 95\% CI 1.4 to 2.92, p<0.001), and organisational context (OR 2.04, 95\% CI 1.41 to 2.96, $\mathrm{p}<0.001$ ).

For the subgroup working in the COVID-19 sector, we only found a higher risk of negative perception of work demand (OR $1.78,95 \%$ CI 1.04 to $3.06, \mathrm{p}=0.03$ ).

Male gender was associated with a negative perception of work demand (OR 2.55, 95\% CI 1.11 to 5.89, $\mathrm{p}=0.02$ ), work activity (OR 2.85, 95\% CI 1.01 to $8.02, \mathrm{p}=0.01$ ), work activity environment (OR 1.9, 95\% CI 1.3 to $2.8, \mathrm{p}=0.0001$ ) and global work environment (OR 3.16, 95\% CI 1.05 to 9.5, $\mathrm{p}=0.04)$. It is also associated with better perception of stress (OR $0.42,95 \%$ CI 0.22 to $0.8, \mathrm{p}=0.008)$ and less physical symptoms (OR $0.42,95 \%$ CI 0.23 to $0.78, \mathrm{p}=0.006$ ).

\section{DISCUSSION}

This large-scale questionnaire survey enrolled 1405 workers of a French university hospital, of whom $66.2 \%$ were HCWs. Almost a third of the participants declared experiencing stress $(32.6 \%)$, work demand $(31.88 \%)$ and physical symptoms $(31.38 \%)$. Our study indicated that being an HCW and a male was a risk factor for a negative perception of work demand and work activity environment. Being female and an HCW was a predictive factor for having a negative perception of stress. HCWs declared a significantly greater impact on overall and mental health and a negative perception of organisational context and work activity. Front-line workers reported significantly higher negative impact of work demand.
In their review of 59 studies on the health impact of the COVID-19 pandemic on HCWs, Muller et al found that the percentage of anxiety ranged from $9 \%$ to $90 \%$, depression from $5 \%$ to $51 \%$, those suffering from sleep problems from $34 \%$ to $65 \%$, and distress from $7 \%$ to $97 \%$. On assessment, certainty of the reported results was very low. Few studies included comparative data from before the pandemic and few compared HCWs with nonHCWs. The risk factors for mental health problems most commonly found were exposure to COVID-19, female gender and worries about the dangers of infection to the worker themselves or of them infecting others. ${ }^{4}$ In our study, we found higher reported stress among HCWs and women than in other groups, but not for front-line workers. Social support had been noted as a protective factor in some previous studies. In our study population, majority of whom were women and aged between 35 and 44 years and conducted during a period when schools were closed, the level of family demand would likely have been high. To confirm this aspect, one of the most frequently reported forms of support for HCWs in our hospital was new childcare services. Correspondingly, in a study on anxiety level among physician mothers in the USA, $18 \%$ reported severe anxiety. ${ }^{20}$ In a Danish study, front-line employees outside the hospital sector had a higher reported rate of fear about infection and transmission to the private sphere when they worked for an ambulance service or in eldercare and the authors pointed out differences in risk management to explain this. ${ }^{21}$ These findings strongly underline that, during 
crises, communication and information are needed by all workers, both HCWs and non-HCWs, especially in hospitals.

An interesting aspect of our study is that we not only compared HCWs in contact with COVID-19 with other HCWs, but also compared all HCWs with other workers in a regional hospital. Multivariate analysis showed that being an HCW was a risk factor for both mental and overall health burden. It highlights that all HCWs were impacted during this period. This had already been observed in previous studies, with higher reports of mental illness reported by second-line workers. ${ }^{4}$ Uncertainty about working conditions, short-notice organisational modifications, and higher work demand due to higher number of staff off work or an increased number of hospitalised patients could impact all HCWs, not only front-line workers. The questions on psychosocial factors revealed that HCWs suffer from higher mental health impact and that the most common causes of psychosocial burden were job strain, especially work demand, organisational context and abilities. As in most French hospitals ${ }^{22}$ the hospital was reorganised during the COVID-19 epidemic, with creation of a dedicated sector for patients with COVID-19, including new workplaces, increased activities and need for specific education for personnel, on the one hand, and on other hand decreasing activities in areas such as surgery. Workers in the non-COVID-19 sector could have felt excluded from the war against the virus and the healthcare group, leading to questions about their usefulness during this period. For most of them, they had to be ready to move to COVID-19 units at any time without having any say in this decision or perspective to make future plans. In France, during the period from March to May 2020, being an HCW, particularly in a hospital, meant receiving a high level of social support and recognition. Some workers told us that it was difficult for them to discuss the crisis when they were at home. They would be simultaneously waiting for a phone call and having information via the media in the same way as the rest of the general population. This duality which led them to avoid social contact so as not to be in presented with this duality.

In July, when we performed this survey, workers identified to have risk factors for developing severe COVID-19 had returned to work at the hospital and were able to participate. This group reported more severe anxiety, which has already been associated with increased depression in $\mathrm{HCW}^{12}$

As in other countries, psychosocial support was provided. ${ }^{23}$ From March to May 2020, the hospital offered two ways for staff to contact a psychologist, one by phone, open 7 days a week, and another through occupational health service during the week only. There were 437 individual consultations of this type, the majority of which were held in occupational health service (89\%). Occupational health professionals also made visits to COVID-19 dedicated units and held 18 group meetings following alerts by an occupational physician or psychologist. They noted anxiety disorders during the lockdown period, and just afterwards an increased number of suicidal ideation and resurgence of latent conflict between units or employees. On the one hand, the most impacted employees were young doctors, medical unit managers, and interestingly workers who stayed at home due to higher health susceptibility to the virus. On the other hand, they reported positive impact in some units, with better collective support and an improved sense of purpose at work. As noted by Greenberg et al, ${ }^{24}$ several mechanisms could help mitigate the moral effect, and in this view team leaders and senior managers have a crucial role. We performed telephone consultations but did not develop other forms of psychological support, such as videoconferencing, telehealth or social networking, described as solutions to limit the impact of social isolation and loneliness during lockdown. HCWs should pay more attention to authoritative information, actively avoiding negative news and preventing information from overwhelming them. Meanwhile, HCWs should also keep in regular contact with families and friends, which can increase not only emotional interaction and psychological support but also mutual encouragement. ${ }^{25}$

Only front-line workers reported a higher impact of work demand. In the first weeks of March, adapted organisation and personal protective equipment were available in the COVID-19 sector of the hospital only. ${ }^{26}$ This is now known to have been a preventive factor for mental health burden during the crisis, as were collective support and a sense of work, already described by psychologists and in the literature. Together, these factors could explain the absence of higher impact on front-line workers. ${ }^{12}$ It seems that work demand was the most important predicting factor for mental health burden in HCWs during this phase of the COVID-19 pandemic. Similar findings were found in a German hospital. ${ }^{27}$ Higher anxiety among front-line workers who are informal caregivers, such as physician mothers, could also be interpreted as an impact of a higher demand both at work and at home. ${ }^{20}$

Our survey was not done during an acute phase of the COVID-19 pandemic, but just after the first peak, and we focused not only on acute health impact but also on medium-term impact and the psychosocial factors implicated. In another longitudinal study from China comparing the mental health of non-HCW employees in January and March 2020, no differences were found for anxiety, depression or stress. ${ }^{28}$ In a population-based study of workers in Japan, fatigue, anxiety, depression and fear about COVID-19 infection increased significantly in HCWs between March and May 2020, but not for nonHCWs, although the latter group represented less than $10 \%$ of those enrolled.$^{29}$ In a double cross-sectional study in Switzerland, with surveys during the COVID-19 peak and after the flattening, higher anxiety was recorded in participants in the first sample than in the second sample, as well as more burnout in the second. ${ }^{16}$ Mental health burden for hospital workers on the second or third line and in support services would be expected to develop a 
few weeks after the peak of the COVID-19 pandemic. This overall effect underlines that preventive action needs to be maintained. We expect to build a longitudinal study with the same methods (SATIN questionnaire, email) in summer 2021.

\section{Strengths and limitations}

We were able to include a large population of workers from the same healthcare structure (a variety of occupation type, age, years at workplace) in this survey. This approach could limit demographic bias such as lifestyle factors and incidence of COVID-19 infection during the study period. The standardised validated questionnaire used in the study was in French and was designed for large institutions and companies.

Our study has some limitations. Bias may arise from the survey having been done via the internet. Data were selfreported and the time required to complete the survey was almost $15 \mathrm{~min}$, which could have increased response bias. The sample may be biased in terms of working conditions and workplaces, especially as very few hospital cleaners and ambulance service personnel answered. We were not able to compare HCWs from intensive care units with others and also to compare between levels of education. ${ }^{30}{ }^{31}$ All participants were from the same province, which also limits generalisation of our findings. We did not have data on lifestyle factors, family status or time they had occupied their present work position. The study also lacks a longitudinal follow-up and did not take into account any pre-existing health symptoms or psychosocial factors.

All HCWs, not only front-line workers, had a greater mental health burden in the weeks after the end of the first peak of the COVID-19 pandemic in France. Psychosocial factors such as work demand, abilities and organisational context were the most relevant factors to assess for risk management and prevention. Female gender was also a risk factor for self-reported stress. We can hypothesise that women have a greater overall mental load related to family life. Similarly, the large variations in activities within the services could weaken collective support. It should not however be forgotten that there is also a high impact on the mental health for workers whose work activities are reduced or who are at home due to health susceptibility to COVID-19. Social support, information provided to employees at work and at home during crises, and action towards rebuilding collective support may be needed in such crises to prevent health impacts on hospital workers of all kinds.

Acknowledgements The authors acknowledge Annette Leclerc for her kind and relevant advice.

Contributors Study design: DL, SB, BME, AG, RP, BL. Data analysis: DL, BME. Manuscript draft version: DL, SB, BL, RP, JD-D, TL. author acting as guarantor: DL

Funding The authors have not declared a specific grant for this research from any funding agency in the public, commercial or not-for-profit sectors.

Competing interests None declared.

Patient consent for publication Not required.
Ethics approval This study involves human participants and was approved by the ethical committee of Brest Hospital (reference B2021CE19). Participants gave informed consent to participate in the study before taking part.

Provenance and peer review Not commissioned; externally peer reviewed.

Data availability statement Data are available upon reasonable request. Data are available from the corresponding author.

Supplemental material This content has been supplied by the author(s). It has not been vetted by BMJ Publishing Group Limited (BMJ) and may not have been peer-reviewed. Any opinions or recommendations discussed are solely those of the author(s) and are not endorsed by BMJ. BMJ disclaims all liability and responsibility arising from any reliance placed on the content. Where the content includes any translated material, BMJ does not warrant the accuracy and reliability of the translations (including but not limited to local regulations, clinical guidelines, terminology, drug names and drug dosages), and is not responsible for any error and/or omissions arising from translation and adaptation or otherwise.

Open access This is an open access article distributed in accordance with the Creative Commons Attribution Non Commercial (CC BY-NC 4.0) license, which permits others to distribute, remix, adapt, build upon this work non-commercially, and license their derivative works on different terms, provided the original work is properly cited, appropriate credit is given, any changes made indicated, and the use is non-commercial. See: http://creativecommons.org/licenses/by-nc/4.0/.

ORCID iD

David Lucas http://orcid.org/0000-0001-8201-0808

\section{REFERENCES}

1 Brand SL, Thompson Coon J, Fleming LE, et al. Whole-system approaches to improving the health and wellbeing of healthcare workers: a systematic review. PLoS One 2017;12:e0188418.

2 Sim MR. The COVID-19 pandemic: major risks to healthcare and other workers on the front line. Occup Environ Med 2020;77:281-2.

3 Allan SM, Bealey R, Birch J, et al. The prevalence of common and stress-related mental health disorders in healthcare workers based in pandemic-affected hospitals: a rapid systematic review and metaanalysis. Eur J Psychotraumatol 2020;11:1810903.

4 Muller AE, Hafstad EV, Himmels JPW, et al. The mental health impact of the covid-19 pandemic on healthcare workers, and interventions to help them: a rapid systematic review. Psychiatry Res 2020;293:113441.

5 Pappa S, Ntella V, Giannakas T, et al. Prevalence of depression, anxiety, and insomnia among healthcare workers during the COVID-19 pandemic: a systematic review and meta-analysis. Brain Behav Immun 2020;88:901-7.

6 Vindegaard N, Benros ME. COVID-19 pandemic and mental health consequences: systematic review of the current evidence. Brain Behav Immun 2020;89:531-42.

7 Bueno-Notivol J, Gracia-García P, Olaya B, et al. Prevalence of depression during the COVID-19 outbreak: a meta-analysis of community-based studies. Int J Clin Health Psychol 2021;21:100196.

8 Olaya B, Pérez-Moreno M, Bueno-Notivol J, et al. Prevalence of depression among healthcare workers during the COVID-19 outbreak: a systematic review and meta-analysis. J Clin Med 2021;10:3406.

9 Santabárbara J, Bueno-Notivol J, Lipnicki DM, et al. Prevalence of anxiety in health care professionals during the COVID-19 pandemic: a rapid systematic review (on published articles in MEDLINE) with meta-analysis. Prog Neuropsychopharmacol Biol Psychiatry 2021;107:110244.

10 Santabárbara J, Lasheras I, Lipnicki DM, et al. Prevalence of anxiety in the COVID-19 pandemic: an updated meta-analysis of communitybased studies. Prog Neuropsychopharmacol Biol Psychiatry 2021;109:110207.

11 Lin K, Yang BX, Luo D, et al. The mental health effects of COVID-19 on health care providers in China. Am J Psychiatry 2020;177:635-6.

12 Young KP, Kolcz DL, O'Sullivan DM, et al. Health care workers' mental health and quality of life during COVID-19: results from a MidPandemic, national survey. Psychiatr Serv 2021;72:122-8.

13 García-Fernández L, Romero-Ferreiro V, López-Roldán PD, et al. Mental health impact of COVID-19 pandemic on Spanish healthcare workers. Psychol Med 2020:1-3.

14 Davido B, Gautier S, Riom I, et al. The first wave of COVID-19 in hospital staff members of a tertiary care hospital in the greater Paris area: a surveillance and risk factors study. Int $J$ Infect Dis $2021 ; 105: 172-9$. 
15 Burdorf A, Porru F, Rugulies R. The COVID-19 (coronavirus) pandemic: consequences for occupational health. Scand J Work Environ Health 2020;46:229-30.

16 Spiller TR, Méan M, Ernst J, et al. Development of health care workers' mental health during the SARS-CoV-2 pandemic in Switzerland: two cross-sectional studies. Psychol Med 2020:1-4.

17 Tracy DK, Tarn M, Eldridge R, et al. What should be done to support the mental health of healthcare staff treating COVID-19 patients? $\mathrm{Br}$ $J$ Psychiatry 2020;217:537-9.

18 Kop J-L, Althaus V, Formet-Robert N, et al. Systematic comparative content analysis of 17 psychosocial work environment questionnaires using a new taxonomy. Int J Occup Environ Health 2016;22:128-41.

19 Langevin VBS. Satin version 3 health and wellbeing at work questionnaire for assessment, diagnostic and prevention. Références en santé travail 2018;153:125-30.

20 Linos E, Halley MC, Sarkar U, et al. Anxiety levels among physician mothers during the COVID-19 pandemic. Am J Psychiatry 2021:178:203-4.

21 Nabe-Nielsen K, Nilsson CJ, Juul-Madsen M, et al. COVID-19 risk management at the workplace, fear of infection and fear of transmission of infection among frontline employees. Occup Environ Med 2021;78:248-54.

22 Bourmaleau J, Maillard S. [Nurses in multi-disciplinary team to face Sars-CoV-2 in intensive care]. Rev Infirm 2020;69:18-19.

23 Hyun J, You S, Sohn S, et al. Psychosocial support during the COVID-19 outbreak in Korea: activities of multidisciplinary mental health professionals. J Korean Med Sci 2020;35:e211.
24 Greenberg N, Docherty M, Gnanapragasam S, et al. Managing mental health challenges faced by healthcare workers during covid-19 pandemic. BMJ 2020;368:m1211

$25 \mathrm{Ye} \mathrm{J}$. Advancing mental health and psychological support for health care workers using digital technologies and platforms. JMIR Form Res 2021;5:e22075.

26 Picard J, Cornec G, Baron R, et al. Wearing of face masks by healthcare workers during COVID-19 lockdown: what did the public observe through the French media? J Hosp Infect 2020;106:617-20.

27 Zerbini G, Ebigbo A, Reicherts P, et al. Psychosocial burden of healthcare professionals in times of COVID-19 - a survey conducted at the University Hospital Augsburg. Ger Med Sci 2020;18:Doc05.

28 Wang C, Pan R, Wan X, et al. A longitudinal study on the mental health of general population during the COVID-19 epidemic in China. Brain Behav Immun 2020;87:40-8.

29 Sasaki N, Kuroda R, Tsuno K, et al. The deterioration of mental health among healthcare workers during the COVID-19 outbreak: a population-based cohort study of workers in Japan. Scand J Work Environ Health 2020;46:639-44.

30 Altmayer V, Weiss N, Cao A, et al. Coronavirus disease 2019 crisis in Paris: a differential psychological impact between regular intensive care unit staff members and reinforcement workers. Aust Crit Care 2021;34:142-5.

31 Gorlier E, Lenfant G, Papas A, et al. [The commitment of trainers at the height of the health crisis]. Rev Infirm 2020;69:30-2. 